March 2008

Volume 3, Number 1

\title{
Flavio Baroncelli: A Personal Recollection ${ }^{1}$
}

by Mikael M. Karlsson

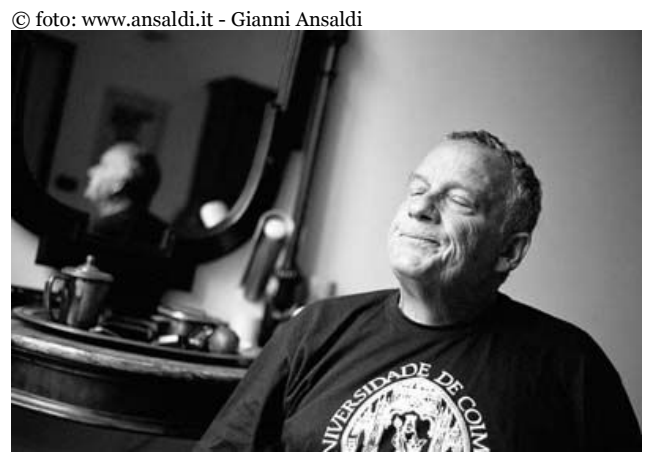

\section{Flavio the Academic: A Brief Curriculum}

This memoire begins, as it must, by recounting some of the facts about the academic life of a good friend-too early departed and profoundly missed-Flavio Baroncelli.

Flavio was born in Savona on January 15th, 1944. He attended the University of Genoa and completed his laurea degree in 1969 with a dissertation on David Hume, written under the supervision of Professor Romeo Crippa. Between 1969 and 1975. Flavio worked as Crippa's assistant and in 1976, in the light of independent research conducted in the U.K. published his first book, Un inquietante filosofo perbene - Saggio su David Hume (A Disquieting, Respectable Philosopher - Essay on David Hume; Florence: La Nuova Italia, 1976).

Between 1974 and 1977, Flavio taught History of the Age of Enlightenment at the University of Trieste, returning to Genoa in 1977 to teach History of Modern Philosophy. He was co-founder, with Gianni Francioni, of the journal, Studi settecenteschi, and worked together with Giovanni Assereto, Franz Brunetti, Salvatore Rotta and other historians of the Enlightenment.

In the early 80 's, Flavio's examination of the cultural and political processes of modernity caused his attention to shift towards the ideological and social aspects of inequality and poverty. In 1983 he and Giovanni Assereto co-authored a book entitled Sulla povertà, idee leggi e progetti nell'Europa moderna (On Poverty. Ideas, Laws and Projects in Modern Europe; Genova-Ivrea: Herodote), whose content is indicated by its title.

In 1981, Flavio was appointed Full Professor in Moral Philosophy at the University of Calabria, returning once more to the University of Genoa in 1982 as Full Professor in Moral Philosophy.

In the early 9o's, his interests shifted once again towards issues in contemporary political philosophy: the theory and practice of toleration, the causes and evils of racism, the standing of liberal theory vs. the communitarian challenge, and the faults and virtues of "political correctness". Along with many journal articles on these topics, he published two books: Il razzismo è una gaffe. Eccessi e virtù del "politically correct" (Racism Is a Gaffe. Excesses and Virtues of the "Politically Correct"; Rome: Donzelli, 1996) and Viaggio al termine degli Stati Uniti. Perché gli americani votano Bush e se ne vantano (Voyage To the Limits of the United States. Why the Americans Elected Bush And Boast About It; Rome: Donzelli, 2006).

Il razzismo è una gaffe is an analysis of political correctness as a cultural phenomenon. Flavio explains how it came about in the United States and examines the main debates that it generated. The first part of the book, which is mainly reconstructive, paints a very illuminating fresco of the cultural and political processes behind the battles around speech codes on American campuses and their reception in Italy. In the second part of the book, through a very deep analysis that resorts to the conceptual tools of moral and political philosophy and pragmatics, Flavio defends political correctness as a way to achieve a fairer and more tolerant society, notwithstanding its excesses and faults. To Flavio's surprise and delight, this book was adopted as an introductory text in sociolinguistics in more than one university course in Italy.

In his last book, Viaggio al termine degli Stati Uniti, Flavio follows a formula very similar to the one used in the preceding book: he intertwines a narrative description of a long trip to the United States (written in Little Rock, Arkansas, where he was intermittently treated for the protracted illness that ultimately killed him) with philosophical reflections on the opposition between the liberal culture and the neo-conservative culture that was at its apex at the time.

In 2006, Flavio changed the institutional disciplinary area of his professorship to political philosophy

Flavio died on February 20th, 2007, at Saint Martin's Hospital of Genoa after a long battle with leukemia. He was in his 64th year².

\section{Flavio the Philosopher}

Flavio Baroncelli was a formidable philosopher, albeit an unusual-and even "disquieting"-one. His work is well known in Italy, but little known in other countries. The obvious explanation for this is that Flavio wrote and published almost exclusively in Italian. And that was no accident, for he knew English well and could easily have written much more in English in order to raise his international profile. But for Flavio, the Italian language was a basic philosophical instrument. He employed a great deal of straightforward (and clever) analytical argument. But he also argued (like Nietzsche) by means of humor, irony, story-telling and various forms of linguistic artistry. For this, he needed Italian, in which language he was a master craftsman.

Flavio understood and cultivated the rhetorical aspect of philosophical writing. He seems not to have viewed rhetoric and reasoning as disjoint enterprises, in the manner of Socrates (who also viewed them as antagonistic enterprises), but rather as intersecting. Of course he understood that rhetoric could be malignant, but, like Aristotle, thought that there was also benign, or constructive rhetoric-rhetoric with a legitimate, and thus rational, persuasive force. His admiration for Hume was in large part based upon his appreciation of Hume's skill as a rhetorician, but what he valued was Hume's employment of constructive rhetoric, while he rejected Hume's all-too-frequent descents into sophistry. In a short piece that recently appeared in English translation, "Rawls and Hume: A Fable" (tr. Gillian Parker), ${ }^{3}$ Flavio imagines a conversation between Hume and Rawls upon the latter's arrival at the Elysian Fields. Hume there is made to remark to Rawls that "rhetoric really isn't your strong point"; and this is meant as a criticism. More specifically, Flavio's Hume chastises Rawls for having "invented a ridiculous term"-the original position-to describe a "simple and brilliant idea". Part of constructive rhetoric consists in the apt, lucid and illuminating choice of terminology. On the other hand, Hume is made to chastise himself for being unable to make his own account of justice sound appealing "except by adulterating, by subjecting to the most bombastic propaganda, the psychological mechanisms available to me". ${ }^{4}$ This is the sort of rhetoric for which Flavio had little tolerance.

The philosophical methodology that recognizes rhetorical, or perhaps one should say, aesthetic, modes of rational persuasion is indicative of a deeper commitment that Flavio shared with Hume. Humean scholars tend to call this "sentimentalism", a label Flavio would surely have resisted. But whatever one calls it, the idea is that there is a shared human nature which is at once discursive and sympathetic. Rational appeals may be made discursively or sympathetically; it may even be difficult to view these two elements as entirely distinct. As I understand Flavio, this was his view; and I perceive it to be Hume's as well. Indeed, I think that this was Hume's main appeal for Flavio. Flavio felt that the Socratic (or ancient Greek) disjunction between reason and sentiment-or between reason and sympathy-was a false one: one that distorted the nature of human rationality. It was therefore that Flavio rejected all forms of traditional rationalism. In the fable of Rawls and Hume mentioned earlier, Hume confronts Rawls in the following manner:

There's something I just don't get; for instance, resorting to practical reason for stability seems odd to me, a sort of oxymoron, because I'm used to thinking it's the passions that create a minimum of stability, of similarity between us . . . as well as a semblance ... of brotherhood.... [F]or the last two hundred years now you've been ashamed of having an idea of human nature and pretend you can do without it, but what's the result? That you, for example, ... try to restrict the things for which you require mutual consent, as if all you were worried about were restricting the grounds on which someone different from you could say no, while in this way you actually exclude the grounds on which someone different from you could say yes. ${ }^{5}$ 
Of course, Flavio is here speaking for Hume; but I believe that he was also, in this place, speaking for himself.

Both Flavio and Hume treated philosophy as a human activity, situated in history, culture and tradition. It addresses itself to people who have the shared nature mentioned above, who have specific traditions and concerns, and who, in any particular discussion, share a certain language which resonates with their beliefs, emotions and sympathies. Rationalism, on their view, attempts to address bloodless wraiths-parodies of the human being. It is exaggeratedly discursive, ahistorical, unsituated, and liable to slide into fanaticism.

While one can never, I think, fully appreciate Flavio as a philosopher without reading him in Italian (for the reasons I have explained), I believe that understanding the way in which he conceived and practiced philosophy can help those who read him in other languages (and it is to be fervently hoped that his works will be widely translated) to appreciate his work ${ }^{6}$.

\section{Flavio the Humanist}

Flavio identified himself as a philosopher, and he was, indeed, a philosopher by any standard. But he was perhaps even more a humanist.

If you conceive and practice philosophy in Flavio's way, you are almost necessarily drawn to humanistic subjects and are less concerned with the analytic-synthetic distinction or the question whether it would be possible for something to be red and green all over. Flavio began his philosophical researches in the history of modern philosophy; but even in that period, it is clear that what interested him most was the significance of philosophical movements and they way they shaped Modernity: the way they influenced the manner in which people understood themselves, one another, and human relationships (especially moral and political relationships). What did Modernity have to offer in the face of poverty? In the face of war? In the face of racism and oppression? These are the things that Flavio thought and wrote about-and he cared what philosophy could say about them and wanted philosophy to have a
positive and wholesome influence. And of course he moved on from thinking about the significance of modern philosophy for the human condition (Locke, Smith, Hume, Kant) to positive and wholesome influence. And of course he moved on from thinking about the significance of modern philosophy for the human condition (Locke, Smith, Hume, Kant) to
thinking and writing about the significance of contemporary philosophy (Rawls, Walzer, Rorty and others). His movement from the history of philosophy and the history of ideas into moral and political philosophy was inevitable and inexorable.

Flavio's humanism found expression in his intense activity as a contributor to various Italian national magazines and newspapers, such as La Voce, Village, Il diario della settimana and Il Secolo XIX. His writings there focussed almost exclusively upon cultural, social and political issues, and he was an insightful and incisive critic of the contemporary scene. Unlike many such critics, he eschewed all forms of fanaticism, while at the same time offering scathing critiques of the beliefs and practices that conduce to human misery.

Flavio's humanism also expressed itself in research. He co-directed various research projects at local and the national level, sponsored by the Italian Ministry of Universities. Particularly important projects were The Ethico-political Philosophical Lexicon in the Italian Culture of the Eighteenth Century (part of a larger project for the creation of an internet library of the Italian culture, Biblioteca Italiana Telematica), and the work on Equal Respect: Its Nature and Its Normative Implications for Institutions, co-ordinated at the national level by Salvatore Veca.

\section{Flavio the Human Being}

Flavio's philosophy and philosophical humanism were of course reflections of the soul of Flavio the man. Like the author of this memoire, Flavio was in certain respects a superannuated hippy. He was, after all, 24 years old in 1968. There were no doubt many earlier occasions; but the only time that I actually saw Flavio dressed in a dark suit was when I paid my respects to him, or rather to his earthly remains, in the hospital morgue. He most often appeared at the university dressed in blue jeans and a sports shirt. He confronted people on a social, intellectual and emotional basis-not a sartorial one.

And Flavio was a biker! Of course, many if not most younger Italians are devotees of scooters and cycles, but Flavio continued to ride and travel on his motorcycle long after most of his colleagues had moved over to their more comfortable Lancias (or whatnot). In 1988, Flavio had a serious motorcycle accident while traveling in Turkey that incapacitated him for more than a year and kept him from teaching and research. Right up until his death, he suffered from pain in his foot and leg that made it difficult for him to walk for long distances and sometimes kept him in bed.

Flavio was not a softie. He set severe standards for himself and others but was generally (although not always!) gentle in applying them. Humor, irony and sometimes sarcasm were his weapons, rather than aggression or intimidation.

He was typically adored by his students and had the ability to get them deeply engaged in philosophical questions. A class with Flavio did not end when everyone left the room; some of his classes may never end, even now that he's gone.

The highlights of Flavio's personal life were his marriage to Annalisa Siri and the adoption of Gurol, their Turkish son. I met them both at the hospital on a very sad day in February, 2007. In 1997, Annalisa had arranged for my own son to participate in cancer research at the institute where she worked as part of his medical education. This was an indirect consequence of my cooperation with Flavio in the Erasmus program, discussed further below.

During his long, final illness, Flavio was often unable to work at the university. His colleagues missed him and his influence in university affairs, and they were mostly in denial about what from the outside looked clearly like a terminal sickness. "When is Flavio going to come back to work?" one of his close colleagues complained; "We need him!" Of course, I had no answer.

The final period of Flavio's life was unfortunate for more reasons than one. He had had to spend a number of years caring for his aged, and rather difficult, father, which prevented him from traveling and, often, from working as he wished. And when at last liberated from the duties of a faithful son, he became aware of the illness that eventually ended his life.

Being unable to travel was a serious loss for Flavio. He was fascinated by the similarities and differences among peoples and nations and relished international contact in a way that could not be fully served by the Internet. In 1991-92 he was an honorary fellow at the Department of Philosophy of the University of Wisconsin in Madison, and he was a Visiting Professor at the University of Iceland (1994), Glasgow University (1994) and the University of Bergen (1996). He was also instrumental in organizing Erasmus exchanges for students and colleagues in philosophy.

It was through the Erasmus program that I first met Flavio; and it was also through this program that he visited-and became a friend of-Iceland. We went together with a group of students to a country retreat in mid-winter. Ever the speculator about human motivation, Flavio gazed wonderingly out of the window of our bus at the bleak, frozen landscape. "What students to a country retreat in mid-winter. Ever the speculator about human motivation, Flavio gazed wonderingly out of the window of our bus at the bleak, frozen landscape. "What
did those people think when they came here?" he asked, referring to the settlement of Iceland, which began in 874 . "What could they have been thinking of?" He also warned me, "I did those people think when they came here?" he asked, referring to the settlement of Iceland, which began in 874 . "What could they have been thinking of?" He also warned me, "I
hope that you are not sleeping with me in the same cabin. I snore like a bear!" He did snore a bit, but not really with bear-like intensity (as I imagine it). The Icelandic students were as
inspired by him as his Italian students, and discussions continued far into the night. Flavio arranged to send students, and a number of colleagues to Iceland, and to receive Icelandic students and colleagues in Genoa. Eventually, others took over this work, but the lively interchanges between the University of Iceland and the University of Genoa continue.

Socrates described philosophy as a preparation for death. But Socrates viewed the body as a kind of prison for the soul, and daily life (and perhaps even human intercourse generally) as a distraction-at least so Plato tells us. Socrates looked forward to bodily death as a liberation of the soul. This was not Flavio's view. For Flavio, as I maintained earlier, human nature was inseparably discursive, sentimental and understand himself as a soul imprisoned in a body; and he reveled in human intercourse. Despite his fable about a meeting of Hume and Rawls in the Elysian Fields, Flavio did not (I think) believe in a f r life, any more than Hume did. Even if Flavio had believed in an afterlife, he would surely a meeting of Hume and Rawls in the Elysian Fields, Flavio did not (I think) believe in an afterlife, any more than Hume did. Even if Flavio had believed in an afterlife, he would surely have wanted to put it off as long as it was possible to live fulfillingly in an earthly life: a life of language, culture, history, society-and in short what I have twice referred to as "human intercourse". I know from our personal conversations that Flavio-long death; it was a preparation for continuing, deepening and advancing the dialogue.

Flavio faced illness and death bravely, and was able, despite weakness and pain, to write out of his experience a remarkable book (Viaggio al termine degli Stati Uniti); but I doubt that he "went gentle into that good night"; and why should he have?

\section{Flavio Altogether}

I have given a somewhat kaleidoscopic recounting of Flavio as a human being. This was the only way I could think of to present him to the reader, not as an academic, but as a person of flesh and blood.

But what unified the kaleidoscopic Flavio was his curiosity about the human animal and about human relations and his passionate hope that people might grow to treat one another better than they do. This curiosity and hope guided his personal life, his interaction with friends, students, and colleagues, his choice of a career, and his philosophical humanism: the honed instrument of his life pursuit.

We have now lost the bodily Flavio, but the spiritual Flavio lives on-not in the fifth dimension, but in Flavio's own way, in this world. He lives on as long as we remember him, study his work, and are moved by his influence. We will be the better for it. 
1 I express my special thanks to Valeria Ottonelli, who helped me to collect together some of the essential material concerning Flavio's life and work.

2 A bibliography of Flavio's most important work can be found here:

Un inquietante filosofo perbene. Saggio su David Hume, La Nuova Italia, Firenze

1977 Blaise Pascal, Solitudine e storia, antologia degli scritti, scelta, introduzione e note di F. Baroncelli, La Nuova Italia, Firenze

1980 Pauperismo e religione nell'eta moderna (con G. Assereto), «Società e storia», n. 7, 1980

1981 Tra Locke e Smith. Alcune immagini del rapporto col "povero", «Studi Settecenteschi», n. 2

1982 La droga, il sesso, l'Iliade e l'Odissea in Piacere e felicità: fortuna e declino. Atti del $3^{\circ}$ Convegno tra studiosi

di Filosofia Morale (Chiavari - S.Margherita Ligure, 15-17 maggio 1980), a cura di Romeo Crippa, Liviana, Padova, pp. 247-63.

1983 (con Giovanni Assereto) Sulla povertà, idee leggi e progetti nell'Europa moderna, Herodote, Genova-Ivrea

1985 Contro la carità discreta. Misericordia, raziocinio e volontà di non sapere in una polemica cinquecentesca sulla povertà, «Materiali per una storia della cultura giuridica», XV (1985), 1

1987 D. Hume, Scritti morali, traduzione, introduzione e note a cura di F. Baroncelli, La scuola, Brescia

1987 I filosofi e la pace. Atti del $5^{\circ}$ Convegno tra studiosi di Filosofia Morale in memoria di Romeo Crippa (Sanremo, Villa Nobel, 13-15 dicembre 1984), a cura di F. Baroncelli e M. Pasini, Ecig, Genova

1987 Corpo e cosmo nell'esperienza morale. Atti del $4^{\circ}$ Convegno tra studiosi di Filosofia morale (Pietrasanta, 30 settembre-2 ottobre 1982) a cura di Romeo Crippa, edizione a cura di F. Baroncelli e D. Rolando, Paideia, Brescia

1989 Suicidio e garanzie. Riflessioni a proposito di un libro recente, «Materiali per una storia della cultura giuridica», XIX (1989), 2

1993 L'incerta fortuna della critica all'immaginazionismo di James Augustus Blondel, «Studi Settecenteschi»

Cinici e scimmie. Osservazioni sull'anti-etnocentrismo di Montaigne e Rousseau, «Materiali per una storia della cultura giuridica», XXIII (1993), 1

1994 Il linguaggio non offending come strategia di tolleranza, «Materiali per una storia della cultura giuridica», XXIV (1994), 1

1995 Razzismo e verità, «Ragion pratica», III (1995), pp. 79-97

1996 Il razzismo è una gaffe, Eccessi e virtù del "politically correct", Donzelli, Roma

1997 Giustizialismo, «Ragion Pratica», n.7, pp. 119-137

Post-fazione a Lysander Spooner, No treason n.6. La costituzione senza autorità, ed. e trad. di V.Ottonelli, Il Melangolo, Roma

Etica e razionalità. Un finto divorzio?, «Materiali per una storia della cultura giuridica», XXVII (1997), 1, pp. $230-260$

Il riconoscimento e i suoi sofismi, in F. Manti (a cura di), La tolleranza e le sue ragioni, pp. 120-147.

1998 Il riconoscimento e i suoi sofismi, «Quaderni di Bioetica», pp. 120-147.

Come scrivere sulla tolleranza, «Materiali per una storia della cultura giuridica», XXVIII (1998), 1, pp. 49-68.

2000 Razzismo e correttezza politica: la riscossa della natura, in Mezzadra, I confini della globalizzazione, Manifestolibri, Roma

Giudizio, giustizia, giustizialismo, in S. Nicosia (a cura di), Il giudizio. Filosofia, teologia, diritto, estetica. Carocci, Roma, pp. 320-339.

2001 Liberalismo e multiculturalismo in Liberalismo e società giusta, a cura di M. Marsonet, Name, Genova

Le quattro indegnità dei liberali irresoluti. Teoria politica, XVII (2001), pp. 23-47

Il chiliagono della politica mondiale e la povertà della nostra immaginazione, «Ragion pratica», 16 (2001), pp. $135-138$

La tolleranza dell'errore e del disvalore, in V. Dini (a cura di), Tolleranza e libertà, Eleuthera, Milano, pp. 257-276

2005 L'onore dei Labdacidi: religione, politica e familismo nell' Antigone di Sofocle, in M. Ripoli - M. Rubino (a cura di), Antigone. Il mito, il diritto, lo spettacolo, pp. 21-44

2006 Viaggio al termine degli Stati Uniti. Perché gli americani votano Bush e se ne vantano, Donzelli, Roma.

3 Published in Emilio Mazza \& Emanuele Ronchetti, eds. New Essays on David Hume (Milano: FrancoAngeli, 2007), pp. 259-63, and originally presented in Italian at the seminar "La filosofia è politica", held in honor of John Rawls at the University of Milan, 31 Janary 2003.

4 "Rawls and Hume: A Fable", p. 260.

5 "Rawls and Hume: A Fable", p. 261.

$\underline{6}$ Others who know Flavio's work may think differently than I about how it should be understood. This piece reflects my personal view, and should at least be of help to those who have yet to encounter Flavio's philosophy. 